\title{
Looking for consensual protection categories to reduce conservation conflicts in protected areas
}

\author{
Mónica de Castro-Pardo ${ }^{*}$ (iD) Fernando Pérez-Rodríguez ${ }^{2}$ (iD) João Carlos Azevedo ${ }^{3}$ (iD) Vicente Urios ${ }^{4}$ (iD
}

\author{
${ }^{1}$ Departamento de Economía de la Empresa, Universidad Rey Juan Carlos (URJC), 28933, Móstoles, Madrid, Spain. E-mail: monica.decastro@urjc.es. \\ ${ }^{*}$ Corresponding author. \\ ${ }^{2}$ Föra forest technologies, Soria, Spain. \\ ${ }^{3}$ Centro de Investigação de Montanha, Instituto Politécnico de Bragança, Campus de Santa Apolónia, Bragança, Portugal. \\ ${ }^{4}$ Departamento de Ciencias Ambientales y Recursos Naturales, Universidad de Alicante (UA), San Vicente de Raspeig, Alicante, Spain.
}

ABSTRACT: Decision-making in protected areas is often difficult due to an unclear definition of management objectives and indicators for their monitoring. This is frequently related to the coexistence of systems of protected areas at national and regional levels for which management objectives are ambiguous or that are not directly related to protected areas classification standards. In this study, we proposed a participative model based on PROMETHEE II to find consensual protected areas categories based on IUCN framework. This model involved the stakeholder's assessments of management objectives in a protected area and their aggregation based on distance comparisons with objectives of international protected areas standards. The model was tested in the Albufera de Valencia Natural Park, a strongly humanmodified wetland located in Eastern Spain and it allowed the identification of consensual management priorities and the IUCN category $V$ as the equivalent international protected area category for this regional protected area.

Key words: protected areas, governance, conservation goals, PROMETHEE II.

\section{Procurando categorias de proteção consensuais para reduzir conflitos em áreas protegidas}

RESUMO: A tomada de decisão em áreas protegidas é frequentemente um processo dificil pelo facto de não se encontrarem claramente definidos os objetivos de gestão e os indicadores para o seu monitoramento. Tal está habitualmente relacionado com a coexistência de sistemas de áreas protegidas a nível nacional e regional para os quais os objetivos de conservação são ambíguos, ou não se encontram diretamente enquadrados em normas formais de classificação de áreas protegidas. Neste estudo propomos um modelo participativo baseado em "PROMETHEE II" para definir categorias de áreas protegidas consensuais baseadas na estrutura da UICN. Este modelo considera a avaliação dos objetivos de gestão por parte de atores em áreas protegidas, e a sua agregação baseada na comparação de distâncias com os objetivos de normas internacionais destas áreas. O modelo foi testado no Albufera de Valencia Natural Park, uma zona úmida fortemente antropizada localizada no Leste de Espanha, o que permitiu a identificação de prioridades consensuais de gestão e a categoria V da UICN como a categoria internacional de área protegida equivalente para esta área protegida regional.

Palavras-chave: áreas protegidas, governança, objetivos de conservação, PROMETHEE II.

\section{INTRODUCTION}

Management effectiveness evaluation in protected areas is the process of assessing "how well protected areas are being managed - primarily the extent to which management is protecting values and achieving goals and objectives" (HOCKINGS et al., 2006). Recent studies concerning management effectiveness highlighted the need to standardize methodologies for ecological monitoring and science-based research to systematically compare management in protected areas (COAD et al., 2015; GELDMANN et al., 2015; DUDLEY et al., 2016). For this reason, many countries adopted the International Union for Conservation of Nature (IUCN) protected areas management categories (DUDLEY, 2008) to classify protected areas according to clear and monitorable management objectives, allowing comparison of protected areas to be made globally, regionally or nationally.

However, in some countries, like Spain, there is a very complex system of classification and management of protected areas that includes a great disparity of regional and national categories. This creates confusion and coordination problems and makes the assessment and monitoring of protected areas difficult to perform since there is not a clear and consistent correspondence between categories and management objectives (LOPEZ et al., 2007).

Good governance in protected areas can be extremely challenging. Uncertainty and the 
difficulty of coordination between different levels of management in the same area increases the complexity of the decision-making processes (GOSNEL et al., 2017). This can become a serious problem for the assessment of the degree of achievement of conservation goals in protected areas. Moreover, the complexity derived from different protection levels implies difficulties to define the best fitting indicators and methodologies to assess management efficiency in these areas. This problem increases with the establishment of control and monitoring systems at the regional level. The application of an international standard can provide local and regional governments with not just international conservation concepts and guidelines but also with tested tools for assessment and monitoring of management in these areas. Some relevant protected areas in the world have no correspondence with international protection categories (SOUTULLO et al., 2008). In areas that can be related to international systems, the application of international tools for their assessment and monitoring, such as the Rapid Assessment and Prioritization of Protected Area ManagementRAPPAM (COAD et al., 2015) or the Management Effectiveness Tracking Tool-METT (STOLTON \& DUDLEY, 2016) is facilitated. It also makes it easier to implement management programs and to improve them, to use available resources more efficiently, and to enhance governance by establishing synergies between governance levels.

Recently, a new paradigm of good governance emerged, having as essential principle the participation of local communities in decisionmaking processes (GOSNEL et al., 2017). In protected areas, there are usually strong conflicts and complex relationships among multiple and diverse stakeholders with contrasting interests, making the incorporation of participation processes into decision-making processes an urgent necessity (VUCETICH et al., 2018). The development of these processes in conservation faces serious problems such as communication difficulties among stakeholders that prevent them from defending properly their interests and from sharing their different points of view (GÖRG et al., 2016). Multicriteria analysis is a useful approach to incorporate preferences in decision-making processes regarding natural resources management (ARSIĆ et al., 2017; DE CASTRO \& URIOS, 2017; DIAZ-BALTEIRO et al., 2017; MARTTUNEN et al., 2017). Multicriteria methods are particularly helpful in reaching agreements since they are based on a framework structured for discussion among groups with different interests. In the last decade the use of multi-criteria analysis to solve management problems in protected areas has increased considerably (COSTA et al., 2016; POUWELS et al., 2017).

In this study, we propose a novel participative model based on outranking techniques to establish equivalences between protected areas management categories in national and regional systems to categories in a single reference international framework. The model is to be applied in existing protected areas to find a correspondence with the categories of the IUCN classification framework with the involvement of stakeholders in these protected areas. In addition to its formal presentation, we validated the model in the Albufera de Valencia Natural Park. Closeness values measure the similitude of stakeholder's priorities according to an international reference category system, the IUCN management priorities. The analyzed alternatives are seven IUCN protected areas categories based on nine management objectives for protected areas (Table 1). Participation was incorporated through personal interviews and online individual interviews.

\section{MATERIALS AND METHODS}

\section{Study area}

The model we developed was tested in the Albufera de Valencia Natural Park, in the Valencian Community, Spain. Protected areas in the Valencian Community are classified into seven categories: Natural Parks, Natural Areas, Municipal Natural Areas, Nature Reserves, Natural Monuments, Special Importance Places and Protected Landscapes. These categories in the Community are assigned according to the presence of natural and biological features and values (GENERALITAT VALENCIANA, 1994). The Albufera de Valencia Natural Park is a protected coastal wetland, classified regionally as a Natural Park in 1986 and as a wetland of international importance (Ramsar site) in 1991. The area is also recognized as a Special Protection Area (SPA) according to the European Comission Birds Directive and a Site of Community Importance (SCI) according to the European Comission Habitats Directive. It covers an area of 21,120 ha, two thirds of which are devoted to rice cultivation and distributed in small parcels of privately-owned land. Anthropic pressure in the last century has been very intense (PASCUALAGUILAR et al, 2015). Agriculture, fishing and hunting have caused conflicts among stakeholders with different interests.

The proposed model encompasses three steps: i) Individual ranking computation, ii) Aggregation of individual preferences, and iii) 
Table 1 - Importance of management objectives for IUCN protected areas categories (based on DUDLEY, 2008). Scores: (3) High, (2) Medium, (1) Low, (0) Null. Ia-Strict nature reserve; Ib-Wilderness area; II-National park; III-Natural monument or feature; IVHabitat species management area; V-Protected landscape/seascape; and VI-Protected areas with sustainable use of natural resources.

\begin{tabular}{|c|c|c|c|c|c|c|c|}
\hline \multirow[b]{2}{*}{ Management objectives } & \multicolumn{7}{|c|}{ IUCN Categories } \\
\hline & Ia & $\mathrm{Ib}$ & II & III & IV & $\mathrm{V}$ & VI \\
\hline Scientific research & 1 & 3 & 2 & 2 & 2 & 2 & 3 \\
\hline Protection of wilderness & 2 & 1 & 2 & 3 & 3 & 0 & 2 \\
\hline Biodiversity preservation & 1 & 2 & 1 & 1 & 1 & 2 & 1 \\
\hline Education & 0 & 0 & 2 & 2 & 2 & 2 & 3 \\
\hline Tourism & 0 & 2 & 1 & 1 & 3 & 1 & 3 \\
\hline $\begin{array}{l}\text { Protection of natural resources and } \\
\text { cultural resources without use }\end{array}$ & 0 & 0 & 2 & 1 & 3 & 1 & 3 \\
\hline Ecosystem Services & 2 & 1 & 1 & 0 & 1 & 2 & 1 \\
\hline Sustainable use & 0 & 0 & 2 & 2 & 2 & 2 & 3 \\
\hline Cultural values and traditions & 0 & 0 & 0 & 0 & 0 & 1 & 2 \\
\hline
\end{tabular}

Evaluation of the robustness of conjoint results and pinpointing conflicts. Here below we showed how we undertook the steps.

i) Individual ranking computation.

Firstly, the stakeholders' priorities of each management objective for one protected area should be collected. Secondly, the closeness values should be calculated as deviations in absolute value between the priorities of each management objective for each IUCN protected area category (Table 1) and the priorities of each management objective evaluated by each stakeholder.

Thirdly, the scores of deviations are reversed so that higher closeness values indicated greater similarity with IUCN priorities. Thus, the value 3 indicated complete agreement between two priorities and the value 0 indicated complete disagreement.

Once the closeness values have been calculated, a Preference Ranking Organization Method for Enrichment Assessment, PROMETHEE II should be used in order to obtain the intensity of the preferences over each alternative or IUCN category. PROMETHEE II is a methodology based on PROMETHEE, a multi-criteria method developed by BRANS (1982), that belongs to the group of outranking techniques and provided a raking of the set of alternatives under consideration based on improvement relationships (BELTON \& STEWART, 2000). PROMETHEE II allowed to obtain net flows for each alternative, providing complete rankings that can be compared with utility functions, i.e. aggregated preference indices (Eq. 1, 2), positive outranking flows (Eq. 3), negative outranking flows (Eq. 4) and net outranking flows (Eq. 5).

$\Pi(a, b)=\sum_{j=1}{ }^{k} P_{j}(a, b) w_{j}$

$\Pi(b, a)=\sum_{i=1}^{k} P_{i}(b, a) w_{i}^{j}$,

$\Phi^{+}(a)=\frac{1}{n-1} \cdot \sum_{x \in A} I I(x, a)$

$\Phi^{-}(a)=\frac{1}{n-1} \sum_{x \subset A} I I(a, x)$

$\Phi(a)=\Phi^{+}(a)-\Phi^{-}(a)$

Equations 1 and 2 allowed to obtain the aggregate preferences indices for each pair of protection categories $a$ and $b . \pi(\mathrm{a}, \mathrm{b})$ represents how each category $a$ is preferred over $b$ and $\pi(a, b)$ represents how each category $b$ is preferred over $a$. When $\pi(a, b)$ is close to zero there is a weak global preference of $a$ relative to $b$, but when it is close to 1 there is a strong global preference towards $a$. Secondly, each category $a$, belonging to the set of $\mathrm{n}$ categories, is compared with the other n-1 categories to obtain the positive outranking flow and the negative outranking flow, using the aggregated indices. The positive outranking flow expresses how a category $a$ is outranking all the others (Equation 3), so the highest $\Phi+(a$ ) represents the best category of the set. Negative outranking flow expresses how a category $a$ is outranked by all the others (Equation 4), so the lower $\Phi$-(a) represents the best category. PROMETHEE II provided a complete rank of categories, allowing the calculation of the net outranking flow of each alternative with a balance between the positive outranking flow and the negative outranking flow (Equation 5). The highest 
net outranking flow represents the most preferred category. When using the closeness values as inputs in the assessment, the ranking of alternative preferences showed the degree of overlap between the priorities of each participant or group of participants in respect to the reference category.

ii) Aggregation of individual preferences. Usually, decision results of the $s$ group members will be aggregated using a common linear additive procedure. The global net flow $\Phi_{\mathrm{G}}$ is calculated as a weighted average of the individual net flows (Equation 6):

$\Phi_{G}\left(a_{i}\right)=\sum_{p=1}^{P} \sum_{j=1}^{k} \Phi_{p, j}\left(a_{i}\right) \omega_{p^{\prime}}, i=1,2, \ldots, n$

where $\omega_{\mathrm{p}}$ represents the relative importance of the participant $p$.

The importance of each participant in the process is determined using the weights for each participant or groups of stakeholders. This provided flexibility to the process and allowed to develop a complete sensibility analysis to pinpoint the compared preferences between stakeholders.

iii) Evaluation of the robustness of conjoint results and pinpointing conflicts. This step is based on a consistency analysis and a participant's analysis. To validate the consistency of the overall result, a sensitivity analysis on the weights for each participant group is performed to evaluate the joint effect of each individual assessment. In this way the acceptance ranges for each alternative can be approximated. The preferences of park technicians, analyzed independently and compared with the overall results, are involved in the process with that purpose in order to help defining thresholds ensuring conservation goals to start negotiating alternatives with stakeholders.

To identify conflicts between the preferences of each group of participants, we proposed a distance-based methodology based on YU \& LAI (2011) (Equation 7).

$$
d_{k l}^{2}=\left(\sqrt{\left(w_{k}^{D M} Z_{k}-w_{k}^{D M} Z_{l}\right)^{2}}\right)^{2}=\sum_{i=1}^{n}\left(w_{k}^{D M} Z_{k i}-w_{l}^{D M} z_{l i}\right)^{2}
$$

where $\mathrm{k}, 1$ represents the $k^{\text {th }}$ and $l^{\text {th }}$ decision-makers, i.e. $k=1,2, \ldots, p, l=1,2, \ldots, p$ and $i$ denotes the $i^{\text {th }}$ alternative, $\mathrm{i}=1,2, \ldots, \mathrm{n}$.

\section{Stakeholders, survey design and data collection}

To test the model, fifteen participants from the most representative groups of stakeholders (Conservationists, Government, Owners and Staff) were interviewed. The Conservationists group is formed by two representatives of environmentalist associations. The Government group is formed by four representatives of municipalities included in the studied area. The Owners group is formed by four representatives of land owners' associations. The Staff group is formed by the director of the Albufera de Valencia Natural Park and four technicians. They are aware of the major problems related with the natural park, performing in this model a control function.

Each of these individuals is a key actor of their group of stakeholders in the natural park. Therefore; although, the sample is not very large, it is comprised of members that represent well the stakeholders' groups related, directly or indirectly, with the use and management of the protected area. To collect the participants' assessment on the importance of management objectives a Likert survey was designed with four classes: High (3), Medium (2), Low (1) and Null (0).

\section{RESULTS AND DISCUSSION}

In our study area, the most preferred protected area category was Category V (Protected Landscape/Seascape) with a net flow of 0.223 , followed by Category II (National Park) with a net flow of 0.112 (Table 2). Both categories prioritize the sustainable use of natural resources against strict protection. In contrast, the less preferred categories were III (Natural monument) and Ia (Strict Nature Reserve). Category Ia represents a very strict level of protection excluding exploitation of natural resources and Category III allowed sustainable use but it does not address ecosystem services or cultural values and traditions. These results capture well the nature of the Albufera de Valencia Natural Park, a very human modified area with a traditional extensive use of natural resources and very rooted cultural values, especially those related to water management. Socially robust knowledge relies on transparency and participation allowing integration of social preferences in the governance of protected areas in the long run. In the case of the Albufera de Valencia Natural Park, the preferences of stakeholders seem to be related to the use of natural resources and biodiversity conservation but also to the maintenance of cultural values and traditions.

Results for each group of stakeholders indicated a clear global preference for category V (Protected Landscape/Seascape) (Figure 1). Category II (National Park) was ranked second and category Ia (Strict Nature Reserve) last (Figure 1). This brief analysis indicated that the global ranking is consistent with the individual one, showing a satisfactory aggregation of individual results. In addition, the preferred category for all stakeholders 
Table 2 - Global Ranking and Global Net Flow of the protected areas categories for the Albufera de Valencia.

\begin{tabular}{lcc}
\hline IUCN Categories & Rank & Net Flow \\
\hline Ia-Strict nature reserve & 6 & -0.114 \\
Ib-Wilderness area & 5 & -0.044 \\
\hline II-National park & 2 & -112 \\
III-Natural monument or feature & 7 & -0.118 \\
IV-Habitat species management area & 4 & 0.011 \\
V-Protected landscape/seascape & 1 & 3 \\
\hline VI-Protected areas with sustainable use of natural resources & 323 \\
\hline
\end{tabular}

but Government is category V. The dispersion in the results of category Ia was caused by the Owners group, who considered this category not suitable for the Albufera Natural Park (net flow of -0.327 compared to the Conservationists net flow of +0.056 ) (Figure 1). These results agree with our expectations, since category Ia prioritized scientific research objectives and strict biodiversity conservation and it does not consider objectives related to sustainable use, tourism, education or maintenance of natural or cultural heritage.

A sensitivity analysis was performed to assess the robustness of the global results. This specific analysis is not related to conflict resolution since it was assumed that all stakeholders agreed on the result and this stage was suppressed. An increase was observed in the weights assigned by the government members to $70 \%$ among all the stakeholders, i.e. $17.5 \%$ by each government group member and $2.7 \%$ by all other members and the global ranking was not changed, emphasizing the strength of other participants in constructing a final decision. Staff results match with the joint alternatives except for categories Ib and IV. Three best ranked alternatives in the global ranking coincide with those of the Staff.

The distance-based methodology identified the most important conflicts in categories Ia, Ib and IV (Figure 2). Overall, the most important conflicts reported were between Owners and Conservationists and between Owners and Government. Owners were the group with more conflicts with other groups for all protected areas categories. This group presented the highest distances with Conservationists and Government preferences for categories Ia, Ib, IV and

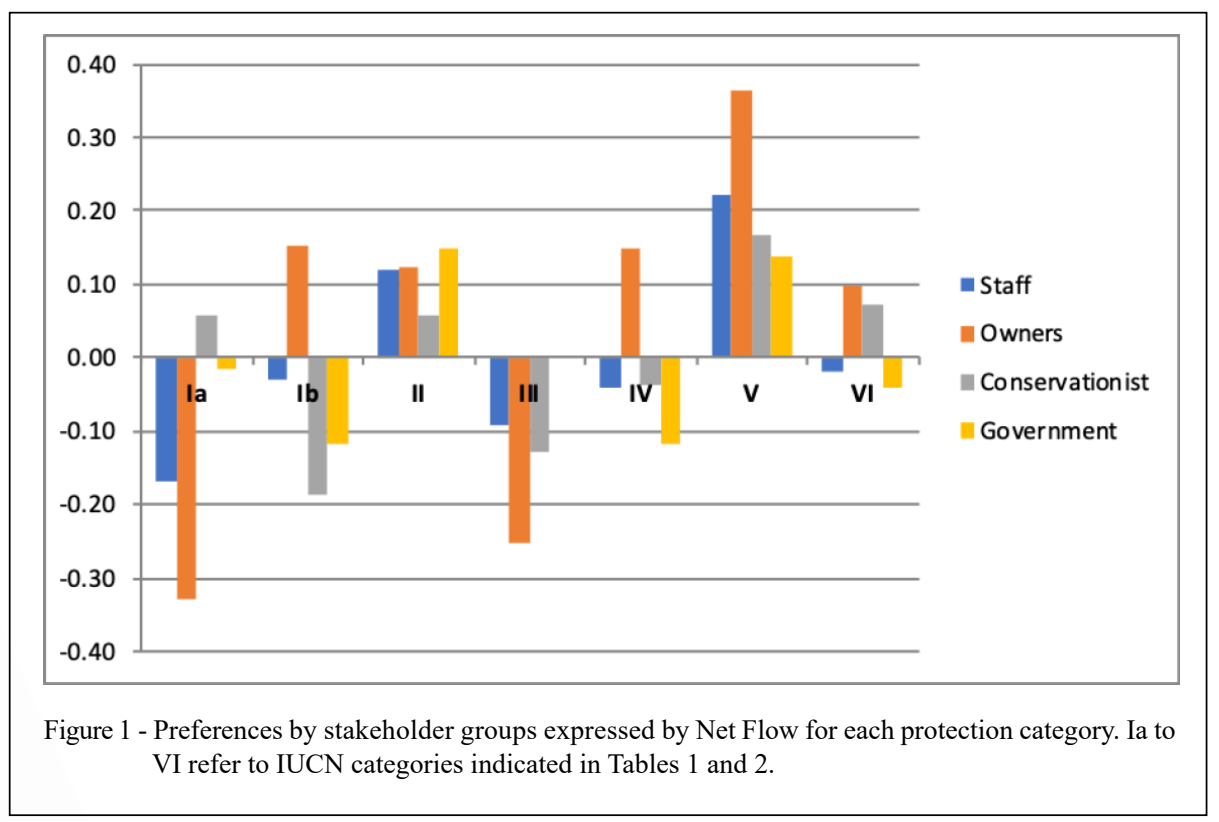

Ciência Rural, v.49, n.12, 2019. 


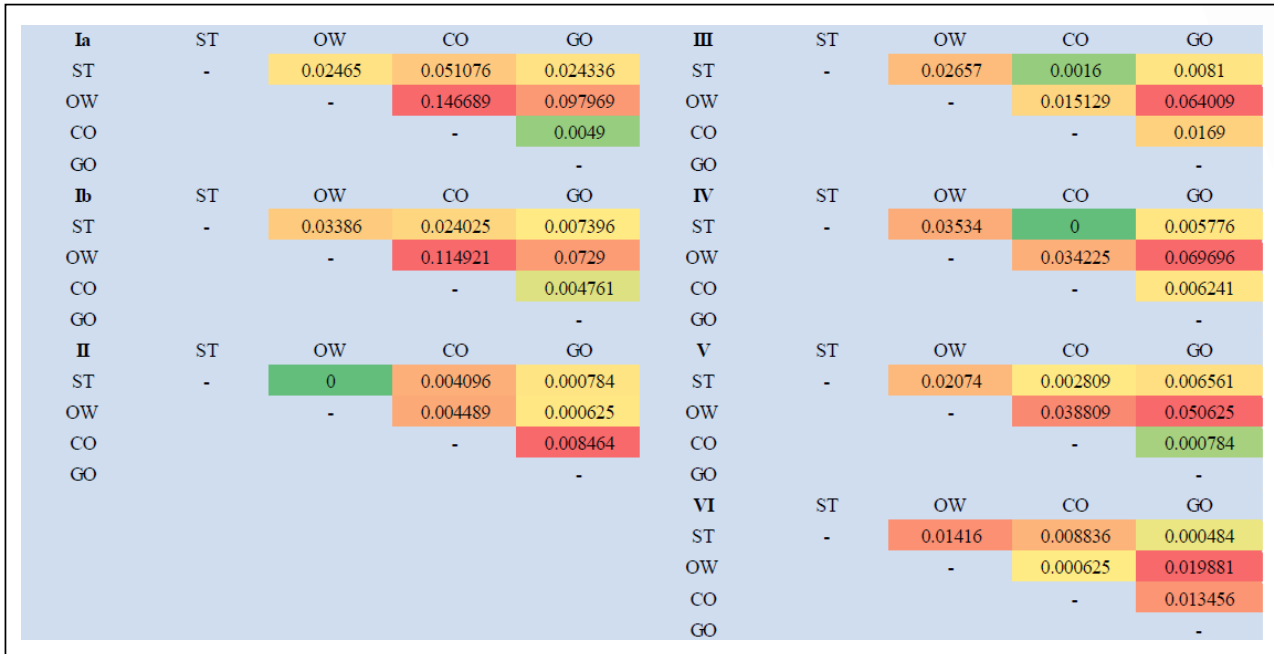

Figure 2 - Distance matrix for each protected area category. ST: Staff, OW: Owners, CO: Conservationists, GO: Government. Ia to VI refer to IUCN categories indicated in Tables 1 and 2.

V. Results also showed conflicts with Conservationists preferences for category II and conflicts with Government preferences for category VI (Figure 2).

These results showed conflicts on protected areas management priorities between some groups of stakeholders, particularly between Owners, Conservationists and Government. Differences in priorities between Government and others stakeholders groups can be a serious problem since the former are responsible for the direct planning and management of the protected area, including regulation of access, land use change and ecosystem management in the area. Government is also responsible for looking for consensus and compromises with all the groups with interests in the area. Conversely, divergences between Owners and Conservationists were very high in extreme values, but they are lower in the medium range. Probably it would be possible to minimize distances prioritizing management objectives that included moderate restrictions and providing clear communication channels between these two groups. Global results were considered robust, identifying IUCN Category V as the most preferred category for the Albufera de Valencia Natural Park.

The model developed in this research and applied in the Albufera de Valencia Natural Park involving the participation of stakeholders in defining priority management objectives of the protected area provides transparency to the design of public policies and helps to improve protected areas policy, ensuring good governance.
This model allowed an easy identification of the strongest conflicts and the groups that are responsible for them. Furthermore, it makes it possible to identify the most conflictive protection categories and quantify the conflict threshold, that is, the score at which one category is preferred over another. This information can be used to enhance communication channels with all relevant actors and to develop collaborative mechanisms providing a space for dialogue and search for solutions to specific problems. The assessment conducted by the protected area staff is a reference to the process as these participants are experts familiar with the problems of the area and who have the responsibility of ensuring nature conservation in the long term throughout decision-making processes.

The need for clear objectives for the planning of protected areas and the lack of systematic approaches for setting it is the main reason to promote this model. The main strengths of the model are its simplicity and generality, which allowed its application to protected areas of any type and in any place in the world. Several multi-criteria models to add stakeholder preferences in protected areas planning have been proposed in the literature (e.g., ANANDA \& HERATH, 2008; COMINO et al., 2016; ESMAIL \& GENELETTI, 2018; GURNEY et al., 2015). Some studies have used these techniques to identify the objectives of protected sites (GUAITA et al., 2019; MARTTUNEN et al., 2019). In comparison to the available models and applications, the added- 
value of our model is that it provides the basis for the aggregation of the stakeholder priorities from early stages of protected areas planning, even before the protection category for a site has been established (including the restrictions related to it) as could be fit well for local people and conflicts could be minimized.

This model also provides transparency in participatory processes indicating each of the individual preferences along the decision-making process. The information thus generated can support the development of specific management strategies for individual protected areas.

\section{CONCLUSION}

The model developed in this research is a strong contribution to the establishment of comparable information systems in the worldwide network of protected areas improving protected areas policy, governance and stakeholders' participation in decision-making. This model enhanced synergies between levels of governance systems and groups of stakeholders with interest in protected areas and in their management. It contributed also to the assessment and monitoring of protected areas of all types.

The application of the model allowed the identification of the IUCN Protected Landscape/ Seascape (Category V) as the international protected area category better fitting the in the Albufera de Valencia Natural Park considering preferences of Owners, Government, Conservationists and Park staff. This suggested that this category is well adapted to the social, economic and social context of the protected area. Category V prioritizes the protection of natural and cultural resources, tourism and maintenance of natural and cultural heritage. As second priorities, it considered scientific research, conservation of biodiversity, conservation of ecosystem services, education and sustainable use of resources.

The model identified conflicts on protected areas management priorities between Owners, Conservationists and Government; although, divergences between owners and conservationists could be smoothed providing non-extreme alternatives.

\section{ACKNOWLEDGEMENTS}

The authors acknowledge all the respondents of the survey for making it possible to apply our model to the Albufera de Valencia Natural Park and three reviewers for their valuable contributions. Authors are grateful to the Foundation for Science and Technology (FCT, Portugal) and ERDF under Programme PT2020 for financial support given to CIMO (UID/ AGR/00690/2019).

\section{DECLARATION OF CONFLICT OF INTERESTS}

The authors declare no conflict of interest. The founding sponsors had no role in the design of the study; in the collection, analyses, or interpretation of data; in the writing of the manuscript, and in the decision to publish the results.

\section{AUTHORS' CONTRIBUTIONS}

The authors contributed equally to the manuscript.

\section{REFERENCES}

ANANDA, J.; HERATH, G. Multi-attribute preference modelling and regional land-use planning. Ecological economics, v.65(2), p.325-335, 2008. Available from: <https://doi.org/10.1016/j. ecolecon.2007.06.024>. Accessed: May, 22, 2019.

ARSIĆ, S. et al. Hybrid SWOT-ANP-FANP model for prioritization strategies of sustainable development of ecotourism in National Park Djerdap, Serbia. Forest Policy and Economics, v.80, 11-26, 2017. Available from: <https://doi.org/10.1016/j. forpol.2017.02.003>. Accessed: May, 22, 2019.

BELTON, V.; STEWART, E. Multiple Criteria Decision Analysis. An Integrated Approach. Kluwer Academic Publishers, 2000.

BRANS, J.P. Lingénierie de la décision:l'elaboration d'instruments d'aide à la décision. Université Laval. Québec, Canada, 1982.

COAD, L. et al. Measuring impact of protected area management interventions: current and future use of the Global Database of Protected Area Management Effectiveness. Philosophical Transactions of the Royal Society B., v.370 (1681), p.1-5, 2015. Available from: <https://doi.org/10.1098/rstb.2014.0281>. Accessed: May, 22, 2019.

COSTA, T.D.O. et al. Defining priority zones for conservation and ecotourism in a protected area. Revista Árvore, v.40 (5), p.769779, 2016. Available from: <http://dx.doi.org/10.1590/010067622016000500001>. Accessed: May, 22, 2019.

COMINO, E., et al. The combined use of Spatial Multicriteria Evaluation and stakeholders analysis for supporting the ecological planning of a river basin. Land Use Policy, v.58, p.183-195, 2016. Available from: <https://doi.org/10.1016/j. landusepol.2016.07.026>. Accessed: May, 22, 2019.

DE CASTRO, M., \& URIOS, V. A critical review of multi-criteria decision making in protected areas. Agricultural and Resource Economics, v.16(2), p.89-109, 2017. Available from: $<$ https://doi. org/10.7201/earn.2016.02.04>. Accessed: May, 22, 2019.

DIAZ-BALTEIRO, L. et al. Measuring systems sustainability with multi-criteria methods: A critical review. European Journal of Operational Research, v.258(2), p.607-616, 2017. Available from: <https://doi.org/10.1016/j.ejor.2016.08.075>. Accessed: May, 22, 2019

Ciência Rural, v.49, n.12, 2019. 
DUDLEY, N. (Editor). Guidelines for Applying Protected Area Management Categories. IUCN. Gland, Switzerland, 2008.

DUDLEY, N. et al. Evidence for biodiversity conservation in protected landscapes. Land, v.5(4), p.38, 2016. Available from: $<$ https://doi.org/10.3390/land5040038>. Accessed: May, 22, 2019.

ESMAIL, B.A.; GENELETTI, D. Multi-criteria decision analysis for nature conservation: A review of 20 years of applications. Methods in Ecology and Evolution, v.9(1), p.42-53, 2018 Available from: <https://doi.org/10.1111/2041-210X.12899>. Accessed: May, 22, 2019

GELDMANN, J. et al. Changes in protected area management effectiveness over time: A global analysis. Biological Conservation, v.191, p.692-699, 2015. Available from: <https:// doi.org/10.1016/j.biocon.2015.08.029>. Accessed: May, 22, 2019.

\section{GENERALITAT VALENCIANA. Ley 11/1994 de Espacios} Naturales Protegidos, 1994.

GÖRG, C. et al. Governance options for science-policy interfaces on biodiversity and ecosystem services: comparing a network versus a platform approach. Biodiversity and Conservation, v.25(7), p.1235-1252, 2016. Available from: <https://doi. org/10.1007/s10531-016-1132-8>. Accessed: May, 22, 2019.

GOSNEL, H. et al. Transforming (perceived) rigidity in environmental law through adaptive governance: a case of Endangered Species Act implementation. Ecology and Society, v.22(4), p.42, 2017. Available from: <https://doi.org/10.5751/ES09887-220442>. Accessed: May, 22, 2019.

GUAITA, J.M., et al. Innovation and multi-level knowledge transfer using a multi-criteria decision making method for the planning of protected areas. Journal of Innovation \& Knowledge, v.4 (4), p.256-261, 2019. Available from: $<$ https://doi.org/10.1016/j. jik.2019.01.001>. Accessed: May, 22, 2019.

GURNEY, G. G., et al. Efficient and equitable design of marine protected areas in Fiji through inclusion of stakeholder specific objectives in conservation planning. Conservation Biology, v.29(5), p.1378-1389, 2015. Available from: <https://doi. org/10.1111/cobi.12514>. Accessed: May, 22, 2019.

HOCKINGS, M. et al. Evaluating effectiveness: a framework for assessing management effectiveness of protected areas. $2^{\text {nd }}$ edition. IUCN, Gland, Switzerland and Cambridge, UK., 2006.
LOPEZ ORNAT, A.et al. Utilización de las categorías de gestión de áreas protegidas de UICN en la región Mediterránea. Consejería de Medio Ambiente de la Junta de Andalucía, Sevilla, España y UICN, Gland, Suiza y Málaga, España, 2007.

MARTTUNEN, M. et al. Structuring problems for Multi-Criteria Decision Analysis in practice: A literature review of method combinations. European Journal of Operational Research, v.263 (1), p.1-17, 2017. Available from: <https://doi.org/10.1016/j. ejor.2017.04.041>. Accessed: May, 22, 2019.

MARTTUNEN, M. et al. Identifying relevant objectives in environmental management decisions: An application to a national monitoring program for river restoration. Ecological Indicators, v.101, p.851-866, 2019. Available from: <https://doi.org/10.1016/j. ecolind.2018.11.042>. Accessed: May, 22, 2019.

PASCUAL-AGUILAR, J. et al. Current anthropogenic pressures on agro-ecological protected coastal wetlands. Science of the Total Environment, v.503, p.190-199, 2015. Available from: $<$ https://doi. org/10.1016/j.scitotenv.2014.07.007>. Accessed: May, 22, 2019.

POUWELS, R. et al. Harmonizing outdoor recreation and bird conservation targets in protected areas: Applying available monitoring data to facilitate collaborative management at the regional scale. Journal of Environmental Management, v.198, p.248-255, 2017. Available from: <https://doi.org/10.1016/j. jenvman.2017.04.069>. Accessed: May, 22, 2019.

SOUTULLO, A. et al. Linking political and scientifically derived targets for global biodiversity conservation: implications for the expansion of the global network of protected areas. Diversity and Distributions, v.14(4), p.604-613, 2008. Available from: $<$ https://doi. org/10.1111/j.1472-4642.2007.00445.x>. Accessed: May, 22, 2019.

STOLTON, S.; DUDLEY, N. METT Handbook: A guide to using the Management Effectiveness Tracking Tool (METT). Woking: WWF-UK, 2016.

VUCETICH, J.A. et al. Just conservation: What is it and should we pursue it? Biological Conservation, v.221, p.23-33, 2018. Available from: <https://doi.org/10.1016/j.biocon.2018.02.022>. Accessed: May, 22, 2019.

YU, L.; LAI, K.K. A distance-based group decision-making methodology for multi-person multi-criteria emergency decision support. Decision Support Systems, v.51(2), p.307-315, 2011. Available from: <https://doi.org/10.1016/j.dss.2010.11.024>. Accessed: May, 22, 2019. 